\title{
Co-nanoencapsulation of magnetic nanoparticles and selol for breast tumor treatment: in vitro evaluation of cytotoxicity and magnetohyperthermia efficacy
}

\author{
This article was published in the following Dove Press journal: \\ International Journal of Nanomedicine \\ 4 October 2012 \\ Number of times this article has been viewed
}

\author{
Luciana LC Estevanato' \\ Jaqueline R Da Silva' \\ André $M$ Falqueiro ${ }^{2}$ \\ Ewa Mosiniewicz- \\ Szablewska ${ }^{3}$ \\ Piotr Suchocki ${ }^{4,5}$ \\ Antônio C Tedesco 2 \\ Paulo C Morais 6 \\ Zulmira GM Lacava' \\ 'Instituto de Ciências Biológicas, \\ Universidade de Brasília, Brasília DF, \\ Brazil; '2Departamento de Química, \\ Laboratório de Fotobiologia e \\ Fotomedicina, Faculdade de Filosofia, \\ Ciências e Letras de Ribeirão Preto, \\ Universidade de São Paulo, Ribeirão \\ Preto SP, Brazil; ${ }^{3}$ Institute of Physics, \\ Polish Academy of Sciences, Warsaw, \\ Poland; ${ }^{4}$ Department of Drug \\ Analysis, Warsaw Medical University, \\ Warsaw, Poland; ${ }^{5}$ Department of \\ Pharmaceutical Chemistry, National \\ Medicines Institute, Warsaw, Poland; \\ ${ }^{6}$ Instituto de Física, Universidade de \\ Brasília, Brasília DF, Brazil
}

\begin{abstract}
Antitumor activities have been described in selol, a hydrophobic mixture of molecules containing selenium in their structure, and also in maghemite magnetic nanoparticles (MNPs). Both selol and MNPs were co-encapsulated within poly(lactic-co-glycolic acid) (PLGA) nanocapsules for therapeutic purposes. The PLGA-nanocapsules loaded with MNPs and selol were labeled MSE-NC and characterized by transmission and scanning electron microscopy, electrophoretic mobility, photon correlation spectroscopy, presenting a monodisperse profile, and positive charge. The antitumor effect of MSE-NC was evaluated using normal (MCF-10A) and neoplastic (4T1 and MCF-7) breast cell lines. Nanocapsules containing only MNPs or selol were used as control. MTT assay showed that the cytotoxicity induced by MSE-NC was dose and time dependent. Normal cells were less affected than tumor cells. Cell death occurred mainly by apoptosis. Further exposure of MSE-NC treated neoplastic breast cells to an alternating magnetic field increased the antitumor effect of MSE-NC. It was concluded that selol-loaded magnetic PLGA-nanocapsules (MSE-NC) represent an effective magnetic material platform to promote magnetohyperthermia and thus a potential system for antitumor therapy.
\end{abstract}

Keywords: PLGA-nanocapsule, cancer, maghemite nanoparticle, MTT, drug delivery, selenium

\section{Introduction}

In the last decade, the development of drug-delivery systems (DDS) has brought significant advances in antitumor strategies. ${ }^{1-3}$ In general, DDS represent an important tool to improve the efficacy of drugs by increasing their bioavailability in the targeted area, thus enhancing the drug's solubility while decreasing undesirable side effects. ${ }^{4,5}$ A number of nanomaterials, including polymeric nanostructures, magnetic nanoparticles (MNPs), liposomes, and dendrimers, are used as DDS. ${ }^{6,7}$ For instance, biodegradable poly(lactic-co-glycolic acid) (PLGA) polymers are successfully used to encapsulate many chemotherapeutic drugs, ${ }^{8}$ such as paclitaxel, ${ }^{9,10}$ adriamycin, ${ }^{11}$ and doxorubicin. ${ }^{12}$ In particular, MNP based-DDS (MDDS) may achieve special properties. MDDS may be site-guided to a specific target tissue by external gradients of magnetic fields, ${ }^{2}$ and also have the potential to carry out hyperthermia, ${ }^{13,14}$ thus increasing the benefits of DDS.

Hyperthermia performed with MNPs, known as magnetohyperthermia, represents a promising approach for cancer treatment. ${ }^{13,14}$ In this therapy, after binding to cancer cells, MNPs can be exposed to an external alternating magnetic field (AMF), which promotes a controllable increase in the local temperature. ${ }^{15}$ Heating up to about $45^{\circ} \mathrm{C}$ induces damage to the cytoskeleton, and also to the cytoplasm and cell organelle
Correspondence: Zulmira GM Lacava CNANO, Instituto de Ciências Biológicas, Universidade de Brasília, 70910-900, Brasília-DF, Brazil

Tel +556131073087

Fax +556131073087

Email zulmira@unb.br 
membranes, leading to cell death. This effect is observed mainly in neoplastic cells, which are less resistant to the sudden rise in temperature than normal cells. Moreover, magnetohyperthermia can also be used as an adjuvant therapy to conventional cancer treatments by improving the efficacy of chemotherapy and radiotherapy. ${ }^{2}$

A PLGA-MDDS formulation co-encapsulating maghemite nanoparticles and selol (MSE-NC) was recently developed, ${ }^{16}$ aiming to provide a new antitumor therapy. Selol is a mixture of selenitetriglycerides synthesized from sunflower oil, containing selenium (+4) in its structure. ${ }^{17}$ The role of selenium as a chemopreventive and chemotherapeutic agent has been supported by a large number of epidemiological, preclinical, and clinical trials. ${ }^{18}$ Studies suggest that antitumor effect mechanisms of selenium include induction of apoptosis, inhibition of cell proliferation, protection against oxidative stress, and stimulation of immune system. ${ }^{19}$ Indeed, it is suggested that selenium can be used as an adjuvant in chemotherapy due to its ability to restore the sensitivity of neoplastic cells resistant to chemotherapeutic drugs,${ }^{20}$ while protecting normal tissues against toxicity induced by anticancer drugs. ${ }^{21}$ However, selol is highly hydrophobic, a property that impairs its administration via the usual routes. Thus, the entrapment of selol into MDDS represents a promising strategy, improving its solubility while keeping the antitumor potential. Further, the co-encapsulation of selol with MNPs adds the possibility of performing magnetohyperthermia of tumor cells.

Bearing in mind that in vitro tests represent a first step of biomedical application investigations, this study reports on the toxicity of the as-prepared PLGA-nanocapsules (MSE-NC) using both normal (MCF-10) and carcinoma breast cell cultures (4T1 and MCF-7). To date, the effects of selol on normal and breast tumorigenic cells have not been reported. As a control, the cytotoxicity of PLGAnanocapsules loaded only with selol (SE-NC) and PLGAnanocapsules loaded only with MNPs (M-NC) was similarly assessed. Subsequently, the efficacy of the as-prepared MSE-NC sample to carry out magnetohyperthermia when exposed to an external AMF was also evaluated.

Our results show that selol-loaded magnetic nanocapsules induced dose and time dependent cytotoxicity. At lower doses, MSE-NC leads to a decrease in viability of neoplastic cells while not inducing any effect on the normal cell line. Notably, the cytotoxic effect was increased by AMF exposure. The findings suggest that MSE-NC represent a potential MDDS for breast cancer treatment able to carry out the magnetohyperthermia technique while potentiating the selol cytotoxic effect.

\section{Materials and methods \\ Nanocapsules}

PLGA-nanocapsules loaded with MNPs and selol (MSE-NC), PLGA-nanocapsules loaded with MNPs (M-NC), PLGAnanocapsules loaded with selol (SE-NC), as well as the control samples, were used in this study. Selol (5\% of selenium) was provided by the Department of Drug Analysis and by the Department of Pharmaceutical Chemistry from the Warsaw Medical University (Warsaw, Poland).${ }^{17}$ The polymeric nanocapsules were prepared according to a modified precipitation method previously described. ${ }^{16}$ Briefly, PLGA 50:50 polymer (Sigma-Aldrich Co, St Louis, MO), selol 5\%, and phosphatidylcholine (Gerbras, Anápolis, Brazil) were dissolved in acetone (JT Baker, Phillipsburg, NJ) at $40^{\circ} \mathrm{C}$. This organic phase was added into an aqueous phase containing the poloxamer 188 (Sigma-Aldrich Co) and the ionic magnetic fluid sample (added into the preparation of magnetic nanocapsules). Organic solvent was removed by evaporation under reduced pressure at $40^{\circ} \mathrm{C}$. Finally, the formulations were concentrated to a final volume of $10 \mathrm{~mL}$. The ionic magnetic fluid used to prepare the magnetic nanocapsules (MSE-NC and M-NC) was based on maghemite nanoparticles stabilized in an acid medium and synthesized following the methodology previously reported. ${ }^{22}$ The MSE-NC sample was developed to contain $10 \mathrm{mg} / \mathrm{mL}$ of selol $5 \%$ and $5 \times 10^{11}$ particles $/ \mathrm{mL}$. The control samples (M-NC and SE-NC) were prepared with the same MNPs or selol concentrations found in the MSE-NC sample.

\section{Characterization}

The size and the morphology of nanocapsules and nanosized magnetic particles were assessed by both transmission electron microscopy (TEM, JEOL 1011; JEOL Ltd, Tokyo, Japan $)^{3}$ and scanning electron microscopy (JEOL JSM7001F; JEOL Ltd). TEM images were analyzed and the size distribution of nanocapsules and maghemite nanoparticles were obtained by counting at least 300 units using the Image Pro-Plus 5.1 software (Media Cybernetics, Inc, Rockville, MD). Data (histograms) were curve-fitted using a log normal distribution to determine the nanocapsule and the MNP mean diameter and diameter dispersity index.

Moreover, the mean diameter and diameter dispersity index were also determined by photon correlation spectroscopy (PCS) at a scattering angle of $173^{\circ}$ and $25^{\circ}$, using zetasizer equipment (NanoZS; Malvern Instruments Ltd, Worcestershire, UK). The stability and the surface charge were evaluated by electrophoretic mobility using the same zetasizer system. Analyses were performed using samples diluted with ultrapure water. 


\section{Cell culture}

Murine mammary carcinoma cells (4T1 cells, provided by Dr Suzanne Ostrand-Rosenberg, Baltimore, MD) and MCF-7 human mammary carcinoma cells (purchased from American Type Collection [ATCC], Manassas, VA) were maintained in Dulbecco's modified Eagle's medium (Gibco ${ }^{\circledR}$, Life Technologies Corporation, Carlsbad, CA) supplemented with $10 \%$ $(\mathrm{v} / \mathrm{v})$ fetal bovine serum $\left(\mathrm{Gibco}^{\circledR}\right)$, and $1 \%(\mathrm{v} / \mathrm{v})$ penicillinstreptomycin (Invitrogen, Life Technologies Corporation, Carlsbad, CA). Human normal breast cell line MCF-10A (donated by Dr Maria Mitzi Brentani, USP, São Paulo, Brazil) was cultured in a 1:1 mixture of Dulbecco's modified Eagle's medium and F12 medium supplemented with 5\% horse serum $\left(\right.$ Gibco $\left.^{\circledR}\right)$, epidermal growth factor $(20 \mathrm{ng} / \mathrm{mL}$; SigmaAldrich Co), hydrocortisone $(0.5 \mu \mathrm{g} / \mathrm{mL}$; Sigma-Aldrich Co), bovine insulin $(10 \mu \mathrm{g} / \mathrm{mL}$; Sigma-Aldrich Co), choleric toxin $(100 \mathrm{ng} / \mathrm{mL}$; Sigma-Aldrich Co), and 1\% penicillinstreptomycin. Cells were maintained at $37^{\circ} \mathrm{C}$ in a $5 \% \mathrm{CO}_{2}$ humidified environment during all experiments.

\section{Cell viability assay}

Cells (4T1, MCF-7, and MCF-10A) were seeded into 96-well culture plates at a density of $2.5 \times 10^{3}$ cells $/ \mathrm{mL}$ and allowed to attach for 24 hours. The cytotoxicity was assessed by exposing cells to five different concentrations of MSE-NC $(1 X=25 \mu \mathrm{g} / \mathrm{mL}$ of selol and $/$ or $1.25 \times 10^{9}$ particles $/ \mathrm{mL} ; 2 X=50 \mu \mathrm{g} / \mathrm{mL}$ of selol and/or $2.5 \times 10^{9}$ particles $/ \mathrm{mL} ; 4 \mathrm{X}=100 \mu \mathrm{g} / \mathrm{mL}$ of selol and $/$ or $5 \times 10^{9}$ particles $/ \mathrm{mL} ; 8 X=200 \mu \mathrm{g} / \mathrm{mL}$ of selol and $/$ or $1 \times 10^{10}$ particles $/ \mathrm{mL}$; and $16 \mathrm{X}=400 \mu \mathrm{g} / \mathrm{mL}$ of selol and/or $2 \times 10^{10}$ particles $/ \mathrm{mL}$ ) diluted in growth media, for 24 and 48 hours. Untreated cells and cells incubated with M-NC or SE-NC samples containing, respectively, the same concentrations of MNPs or selol found in the MSE-NC sample were employed as control groups, while positive control cells were treated with paclitaxel ( $40 \mu \mathrm{g} / \mathrm{mL}$; Sigma-Aldrich Co), a chemotherapy agent commonly used for breast cancer treatment. After treatments, cell viability was evaluated using the tetrazolium dye assay (MTT; Invitrogen) ${ }^{23}$ Cells were incubated with a solution of MTT $10 \%$ in culture medium for 2.5 hours. The MTT solution was removed and $200 \mu \mathrm{L}$ of dimethyl sulfoxide (Vetec; Sigma-Aldrich Co, Duque de Caxias, Brazil) was added. The absorbance readings were performed in a spectrophotometer (SpectraMax M2; Molecular Devices, LLC, Sunnyvale, CA) using a microplate reader at a $595 \mathrm{~nm}$ wavelength. The medium absorbance of untreated control groups was considered as $100 \%$ viability and used to calculate the percentage of viable cells after the treatments. The concentration of MSE-NC, which causes inhibition of $50 \%$ cell viability $\left(\mathrm{IC}_{50}\right)$ compared to control cells was calculated using GraphPad Prism (version 5.00; GraphPad Software, Inc, La Jolla, CA).

\section{Cell morphology analysis}

After the same procedure of culture and treatment used to evaluate the cell viability, cells were washed with phosphatebuffered saline (PBS, Laborclin, Rio De Janeiro, Brazil). Cells attached to the plate were fixed in methanol $\left(4^{\circ} \mathrm{C}\right.$, Vetec; Sigma-Alrich Co) and stained with a Giemsa 4\% solution (Doles, Goiânia, Brazil) or Perls' reaction to investigate the cells' morphology.

\section{Annexin-V-FITC/propidium iodide staining analysis}

Translocation of phosphatidylserine in the cell membrane was determined by Annexin-V-FITC and propidium iodide staining. ${ }^{3}$ First, 4T1 and MCF-7 cells were seeded into a 6-well culture plate at a density of $1.25 \times 10^{5}$ cells $/ \mathrm{mL}$, and allowed to attach to the plate for 24 hours. Subsequently, cells were treated with MSE-NC $\left(2 \mathrm{X}=50 \mu \mathrm{g} / \mathrm{mL}\right.$ of selol $+2.5 \times 10^{9}$ particles $/ \mathrm{mL}$ and $8 \mathrm{X}=200 \mu \mathrm{g} / \mathrm{mL}$ of selol $+1 \times 10^{10}$ particles $/ \mathrm{mL}$ ), M-NC $\left(2 \mathrm{X}=2.5 \times 10^{9}\right.$ particles $\left./ \mathrm{mL}\right)$, SE-NC $(2 \mathrm{X}=50 \mu \mathrm{g} / \mathrm{mL}$ of selol), or paclitaxel $(40 \mu \mathrm{g} / \mathrm{mL})$. After incubation for 48 hours, cells were rinsed with PBS, centrifuged and resuspended in $100 \mu \mathrm{L}$ binding buffer (Invitrogen), and $5 \mu \mathrm{L}$ Annexin-V-FITC (Invitrogen). After incubation at $4^{\circ} \mathrm{C}$ in the dark for 15 minutes, $400 \mu \mathrm{L}$ binding buffer and $0.5 \mu \mathrm{L}$ propidium iodide ( $5 \mu \mathrm{g} / \mathrm{mL}$, Invitrogen) were added. Analyses were performed 5 minutes later at $4^{\circ} \mathrm{C}$. To each sample, 10,000 events were analyzed by flow cytometry (CyFlow, Partec $\mathrm{GmbH}$, Munster, Germany) using FlowMax software (Partec $\mathrm{GmbH}$ ).

\section{DNA fragmentation analysis}

After the same procedure of culture and treatment used to evaluate the Annexin-V-FITC and iodide propidium staining analysis, cells attached to the plate were washed with PBS, centrifuged, resuspended in a $200 \mu \mathrm{L}$ lysis buffer $(0.1 \%$ sodium citrate, $0.1 \%$ triton $\mathrm{X}-100$, and $20 \mu \mathrm{g} / \mathrm{mL}$ propidium iodide), and incubated for 30 minutes in the dark at room temperature. To each sample, 5,000 events were evaluated by flow cytometry (CyFlow, Partec $\mathrm{GmbH}$ ).

\section{Antiproliferative effect under alternating magnetic field exposure}

The 4T1 and MCF-7 cell lines were seeded into a 24-well culture plate at a density of $4 \times 10^{4}$ cells $/ \mathrm{mL}$. Twenty-four hours after seeding, cells were treated with MSE-NC 
$\left(2 \mathrm{X}=50 \mu \mathrm{g} / \mathrm{mL}\right.$ of selol $+2.5 \times 10^{9}$ particles $/ \mathrm{mL}$ and $4 \mathrm{X}=100 \mu \mathrm{g} / \mathrm{mL}$ of selol $+5 \times 10^{9}$ particles $\left./ \mathrm{mL}\right)$. The treatment was maintained for 4 hours before removing the medium containing MSE-NC. Attached cells were washed with PBS, and culture medium was added. Cells were then exposed for 3 minutes to the AMF generated by equipment operating at the frequency of $1 \mathrm{MHz}$ and 40 Oe field amplitude. ${ }^{14,24-26}$ Twenty hours after magnetic field exposure, cell viability was evaluated by the MTT assay. Untreated cells exposed or not to the AMF were the negative controls, and absorbance measurements were used to calculate the viable cells percentage after the treatment.

\section{Statistical analysis}

Statistical analysis was carried out using SPSS software (version 19; IBM Corporation, Armonk, NY). Data were expressed as mean \pm standard error of the mean from at least two independent experiments. Statistical significance was accepted at a level of $P<0.05$. Normal distribution of data variances was verified by the Shapiro-Wilk test.
Differences between the groups were investigated through analysis of one-way analysis of variance and Tukey's post-hoc test was chosen to carry out 2-to-2 comparisons between the treatments. Data not presenting normal distribution were tested by Kruskal-Wallis and Mann-Whitney.

\section{Results}

\section{Characterization of nanocapsules}

Electron microscopy analysis revealed that PLGAnanocapsules from the MSE-NC sample presented with a spherical shape and a mean diameter of $235.8 \mathrm{~nm}( \pm 57.6 \mathrm{~nm})$ (see Figure 1). TEM micrographs also revealed that they are individually distributed and present an electron-dense core of maghemite nanoparticles localized inside and also on the nanocapsules' surface (see Figure 1B). The maghemite nanoparticles used to synthesize the magnetic nanocapsules presented a mean diameter of $10.0 \mathrm{~nm}( \pm 2.5 \mathrm{~nm})$, as shown in Figure 2.

For comparison, the morphology of the nanocapsules from M-NC and SE-NC was also evaluated by TEM.
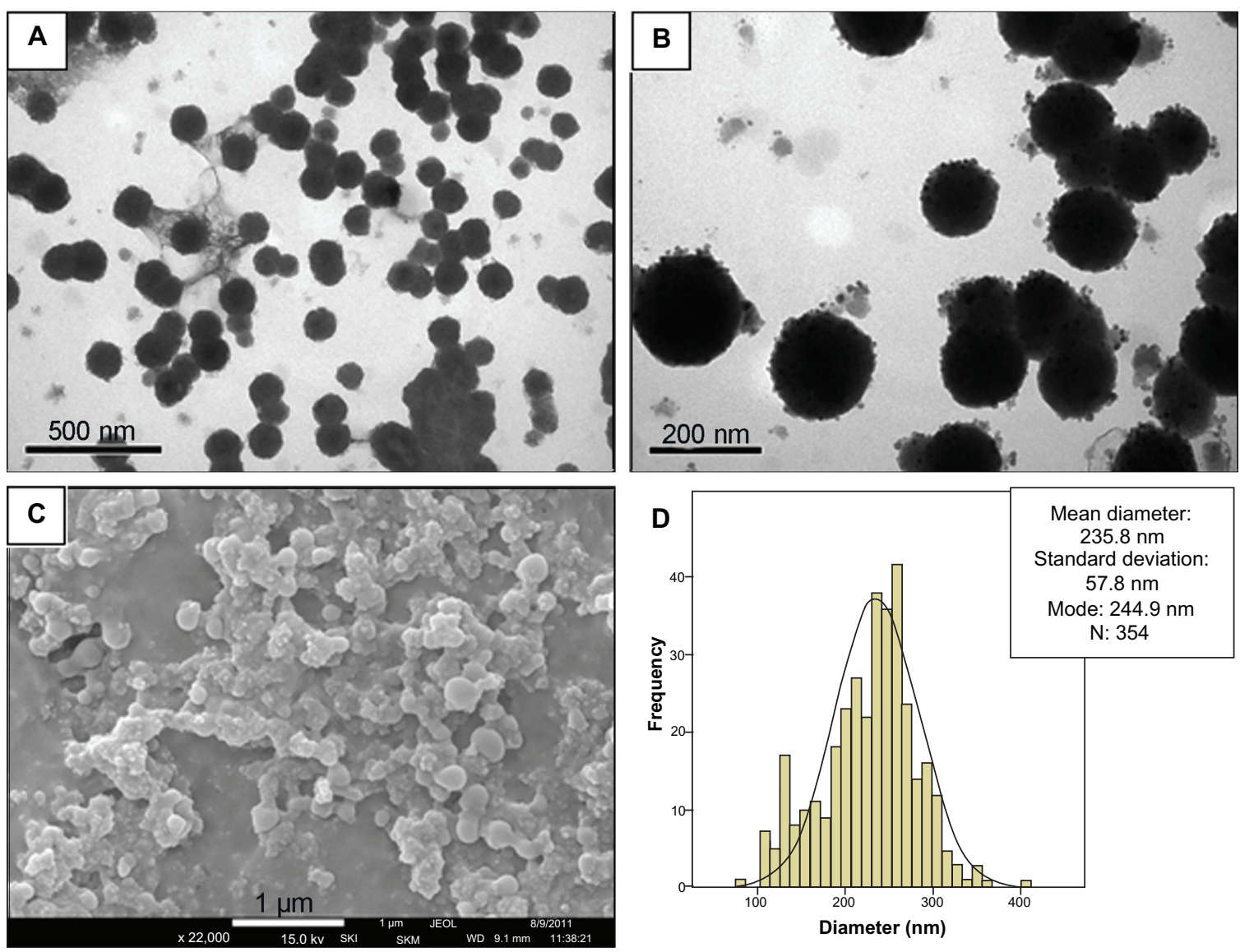

Figure I Characterization of MSE-NC. (A and B) Transmission electron photomicrographs of MSE-NC; (C) Scanning electron photomicrograph of MSE-NC; (D) Histogram of the distribution of MSE-NC diameters.

Abbreviation: MSE-NC, poly(lactic-co-glycolic acid)-nanocapsules loaded with magnetic nanoparticles and selol. 

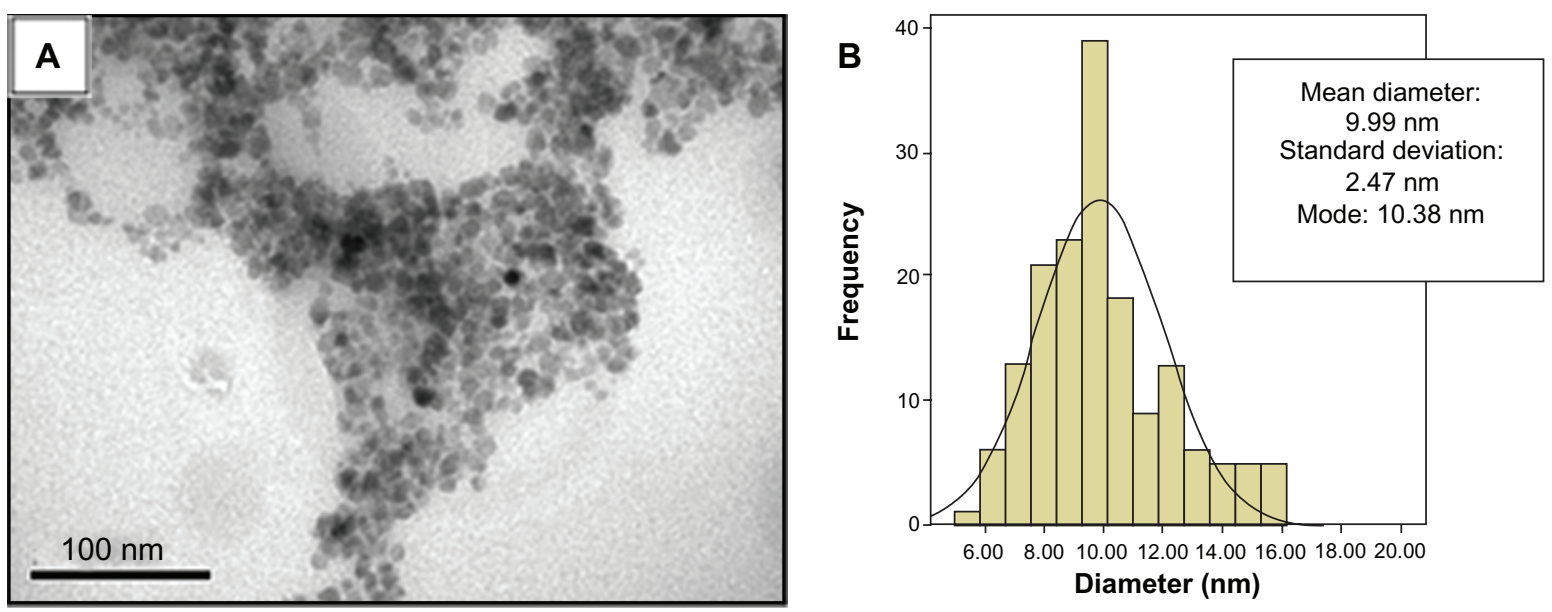

Figure 2 Characterization of maghemite nanoparticles. (A) Transmission electron photomicrograph of maghemite nanoparticles prior to the encapsulation process; (B) Histogram of the distribution of maghemite nanoparticle diameters.

Unlike MSE-NC, nanocapsules from M-NC are organized in clusters with maghemite nanoparticles mainly on their surface (see Figure 3). As for the SE-NC sample, as in MSE-NC, the nanocapsules presented with a spherical shape and were individually distributed (data not shown).

In accordance with analysis of PCS (Table 1) MSE-NC presented with a size similar to that found in TEM analysis, with narrow size distribution evidenced by the size dispersity index of 0.23 . M-NC presented with a higher diameter after evaluation by PCS analysis. In contrast to the M-NC and SE-NC formulations, MSE-NC presents positive charge on zeta potential analysis (Table 1).

\section{Cell viability analysis}

Figure 4 shows the effects of MSE-NC, M-NC, and SE-NC treatments on the cell viability in murine (4T1, Figure 4A)

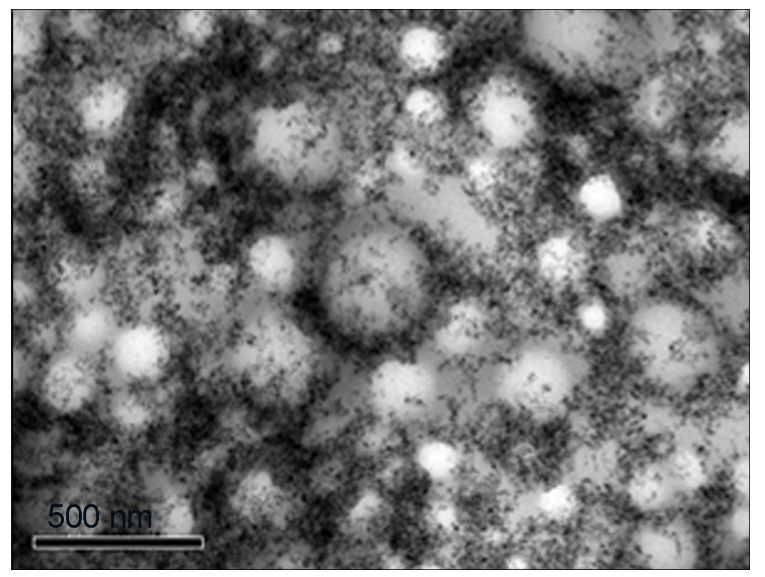

Figure 3 Transmission electron photomicrograph of M-NC showing dispersed nanoparticles on its surface.

Abbreviation: M-NC, poly(lactic-co-glycolic acid)-nanocapsules loaded with magnetic nanoparticles. and human (MCF-7, Figure 4B) breast adenocarcinoma cell lines, as well as in the normal breast cell line (MCF-10A, Figure 4C) in regard to both the concentration of selol and MNPs (represented in columns $1 \mathrm{X}$ to $16 \mathrm{X}$ ) and the treatment time (24 and 48 hours). Data obtained from nontreated cells were considered to exhibit $100 \%$ cell viability. A significant decrease in the viability of $4 \mathrm{~T} 1$ and MCF-7 neoplastic cells was observed after treatments with all formulations (MSE-NC and the control samples, M-NC and SE-NC) and doses evaluated (1X to $16 \mathrm{X}$ ). In general, the murine tumor $4 \mathrm{~T} 1$ cells were less affected than the human tumor MCF-7 cells. Higher concentrations $(200 \mu \mathrm{g} / \mathrm{mL}$ of selol and/ or $1 \times 10^{10}$ particles $/ \mathrm{mL}(8 X)$ and $400 \mu \mathrm{g} / \mathrm{mL}$ of selol and/or $2 \times 10^{10}$ particles $/ \mathrm{mL}(16 \mathrm{X})$ ) were more cytotoxic, especially in the long term treatment. On tumorigenic cell lines, the effects of the M-NC control group (not loaded with selol) were very similar to that observed after MSE-NC treatment in almost all of the evaluated concentrations. Although all of the SE-NC concentrations that were tested induced a significant reduction in neoplastic cell viability, they were less cytotoxic

Table I Characterization of PLGA-nanocapsules from MSE-NC, M-NC, and SE-NC samples by PCS and Zetasizer

\begin{tabular}{llll}
\hline Samples & MSE-NC & M-NC & SE-NC \\
\hline Mean diameter $(\mathrm{nm})$ & $244 \pm 2$ & $949 \pm 100$ & $213 \pm 3$ \\
SDI & $0.23 \pm 0.01$ & $0.87 \pm 0.07$ & $0.31 \pm 0.02$ \\
Zeta potential $(\mathrm{mV})$ & $20.1 \pm 0.7$ & $-11.7 \pm 0.6$ & $-28.6 \pm 0.8$ \\
$\mathrm{pH}$ & 7.4 & 7.5 & 7.0 \\
\hline
\end{tabular}

Note: Data represent mean \pm SEM of three different batches of MSE-NC and the control formulations $\mathrm{M}-\mathrm{NC}$ and SE-NC, at scattering angle of $173^{\circ} \mathrm{C}$ and $25^{\circ} \mathrm{C}$.

Abbreviations: PLGA, poly(lactic-co-glycolic acid); MSE-NC, PLGA-nanocapsules loaded with magnetic nanoparticles and selol; M-NC, PLGA-nanocapsules loaded with magnetic nanoparticles; SE-NC, PLGA-nanocapsules loaded with selol; PCS, photon correlation spectroscopy; SDI, size dispersity index. 


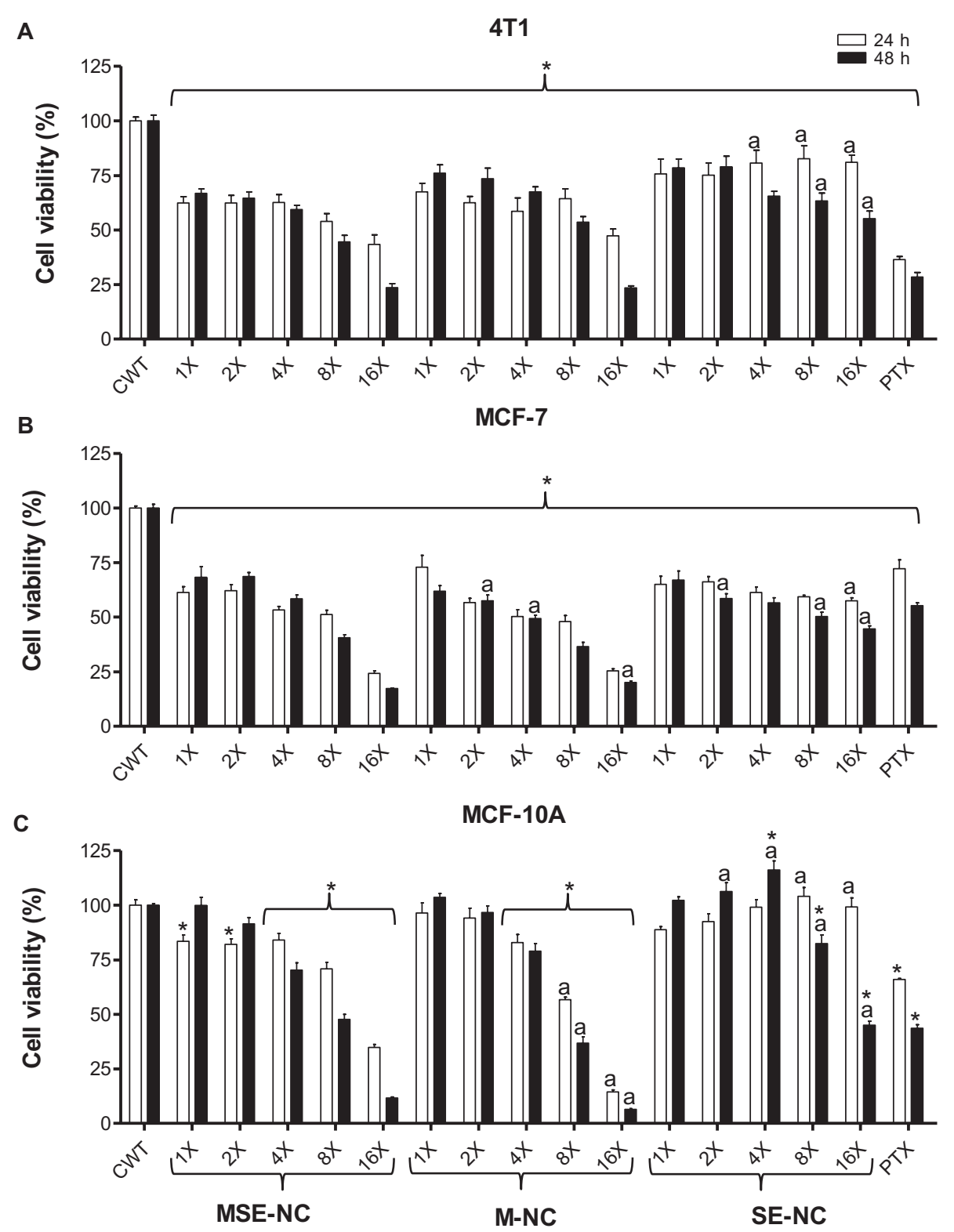

Figure 4 Effects of MSE-NC and control nanoformulation (M-NC and SE-NC) treatments of 24 hours and 48 hours on the viability of 4 TI (A), MCF-7 (B), and MCF-IOA (C) cells.

Notes: Data were normalized with control (untreated) cell viability $(100 \%)$ and expressed as the percentage of the mean \pm SEM of three independent experiments performed in

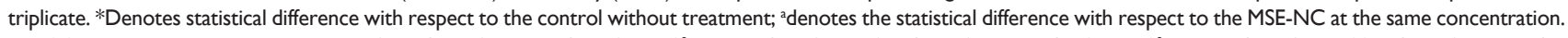
$P<0.05$. The values expressed are IX $-25 \mu \mathrm{g} / \mathrm{mL}$ of selol and $/$ or $1.25 \times 10^{9}$ particles $/ \mathrm{mL} ; 2 X-50 \mu g / \mathrm{mL}$ of selol and $/$ or $2.5 \times 10^{9}$ particles $/ \mathrm{mL} ; 4 X-100 \mu g / \mathrm{mL}$ of selol and $/$ or $5 \times 10^{9}$ particles $/ \mathrm{mL} ; 8 X-200 \mu \mathrm{g} / \mathrm{mL}$ of selol and $/$ or I $\times 10^{10}$ particles $/ \mathrm{mL} ; 16 X-400 \mu g / \mathrm{mL}$ of selol and $/$ or $2 \times 10^{10} \mathrm{particles} / \mathrm{mL}$; PT $-40 \mu g / \mathrm{mL}$ of Paclitaxel. Abbreviations: MSE-NC, selol-loaded magnetic nanocapsules; M-NC, unloaded magnetic nanocapsules; SE-NC, nonmagnetic nanocapsules of selol.

than the magnetic nanocapsules (MSE-NC and M-NC), particularly at higher concentrations ( $8 \mathrm{X}$ and $16 \mathrm{X})$.

Different from what has been observed with tumor cell lines, low doses of encapsulated MNPs, M-NC (1X and 2X), showed no viability reduction while tested against MCF-10A normal cells. Although exposure to lower concentrations of MSE-NC (1X and 2X) for 24 hours had significantly reduced the MCF-10A viability, we found that 48 hours' exposure recovered MCF-10A viability up to $99.9 \%$ (1X) and $91.4 \%(2 \mathrm{X})$. These values were statistically similar to those of the control group without treatment. Interestingly, higher doses of MSE-NC induced less cytotoxicity than $\mathrm{M}-\mathrm{NC}$ on normal breast MCF-10A cells. Furthermore, for all concentrations evaluated after 24 hours of exposure to SE-NC, cytotoxicity was not noted. Surprisingly, only 48 hours of exposure to SE-NC with doses higher than $100 \mu \mathrm{g} / \mathrm{mL}$ (8X and 16X) induced a significant decrease on normal cell viability. 
It is important to note that all studied cells showed sensitivity to paclitaxel, thus validating our experimental model (Figure 4). Data in Figure 4 show that neoplastic cell lines were more sensitive to treatments than normal cells. For instance, lower concentrations of MSE-NC $\left(25 \mu \mathrm{g} / \mathrm{mL}\right.$ of selol $+1.25 \times 10^{9}$ particles $/ \mathrm{mL}[1 \mathrm{X}]$ and $50 \mu \mathrm{g} / \mathrm{mL}$ of selol $+2.5 \times 10^{9}$ particles $/ \mathrm{mL}$ [2X]) induced a drop of around $38 \%$ in the viability of $4 \mathrm{~T} 1$ and MCF-7 breast carcinoma cells, whereas no effect was observed on the viability of the MCF-10A normal breast cell line. The $\mathrm{IC}_{50}$ values (Table 2) confirm that tumorigenic cell lines were more sensitive to the treatment herein described than the normal cell line (MCF-10A); however, $\mathrm{IC}_{50}$ values also showed that increasing the incubation time of normal cells with MSE-NC significantly enhances the treatment's sensitivity.

\section{Cell morphology analysis}

No changes were observed in the cells' morphology while using the different nanocapsule formulations described in this study. However, as the concentration of MSE-NC, $\mathrm{M}-\mathrm{NC}$, and SE-NC increases, fewer adhered cells were observed on the plates (see Figure 5). After treatment with magnetic nanocapsules (MSE-NC and M-NC), brownish aggregates of MNPs were also observed under Giemsa stain. A higher number of clusters consisting of MNPs was visualized as blue pigment on tumorigenic cells (see Figure 6), thus evidencing the higher uptake of MSE-NC in breast tumor cells (4T1 and MCF-7) than in the normal breast cell line (MCF-10A).

\section{Annexin-V-FITC/propidium iodide staining analysis}

Normal, apoptotic, and necrotic cells were distinguished when employing the annexin-V-FITC and propidium iodide staining method. Figure 7 shows the percentage of cells that were positively stained by annexin-V-FITC. MSE-NC,

Table 2 Distribution of the $\mathrm{IC}_{50}$ values and their respective confidence intervals (95\%) in 4TI, MCF-7, and MCF-IOA cell lines after treatment with MSE-NC

\begin{tabular}{lll}
\hline Cell lines & $I_{50}(I C 95 \%)(\mu \mathrm{g} / \mathrm{mL})$ & \\
\cline { 2 - 3 } & $\mathbf{2 4}$ hours & $\mathbf{4 8}$ hours \\
\hline $4 T I$ & I63.I $(I 27.4$ to 208.8$)$ & I2I.2 $(92.4$ to I59.0) \\
MCF-7 & I09.4 (78.7 to I5I.9) & II6.2 (92.6 to I45.9) \\
MCF-IOA & $337.3(301.8$ to 377.0$)$ & I7I.2 (I54.7 to I89.5) \\
\hline
\end{tabular}

Note: The data refer to the cell viability after treatment with MSE-NC $(25 \mu \mathrm{g} / \mathrm{mL}$ of selol + $1.25 \times 10^{9}$ particles $/ \mathrm{mL}$ (IX) to $400 \mu \mathrm{g} / \mathrm{mL}$ selol $+2 \times 10^{10}$ particles $/ \mathrm{mL}(16 X)$ ). Abbreviation: MSE-NC, selol-loaded magnetic nanocapsules.
M-NC, and SE-NC significantly increased the percentage of annexin- $\mathrm{V}^{+}$cells with respect to the untreated control group. The highest concentration of MSE-NC $(200 \mu \mathrm{g} / \mathrm{mL}$ of selol $+1 \times 10^{10}$ particles $/ \mathrm{mL}$ ) induced about seven times more annexin- $\mathrm{V}^{+}$cells $(64.5 \%)$ than the control group $(8.1 \%)$ in both of the evaluated tumorigenic cell lines. However, cells positively stained with iodide propidium were not found.

\section{DNA fragmentation analysis}

MSE-NC, M-NC, and SE-NC induced significant increase in DNA fragmentation of tumor cells with respect to the untreated control group (see Figure 8). The DNA fragmentation induced by MSE-NC treatment was dose-dependent, as observed from the results found at concentrations of $50 \mu \mathrm{g} / \mathrm{mL}$ of selol $+2.5 \times 10^{9}$ particles $/ \mathrm{mL}$ and $200 \mu \mathrm{g} / \mathrm{mL}$ of selol $+1 \times 10^{10}$ particles $/ \mathrm{mL}$, which induced $33.0 \%$ and $62.8 \%$ of DNA fragmentation on 4T1 cell line, and $27.6 \%$ and $72.6 \%$ of DNA fragmentation on MCF-7 cell line, respectively.

\section{Effects of MSE-NC on the cells' viability}

Incubation of 4T1 murine mammary carcinoma cells with MSE-NC $\left(50 \mu \mathrm{g} / \mathrm{mL}\right.$ of selol $+2.5 \times 10^{9}$ particles $/ \mathrm{mL}$ $[2 \mathrm{X}]$ and $100 \mu \mathrm{g} / \mathrm{mL}$ of selol $+5 \times 10^{9}$ particles $\left./ \mathrm{mL}[4 \mathrm{X}]\right)$ induced no significant differences in the cell viability in the absence of the AMF. However, while incubated with MSE-NC at concentrations of $2 \mathrm{X}$ and $4 \mathrm{X}$, and submitted to AMF exposure, 4T1 murine mammary carcinoma cells' viability decreased, respectively, by $31.5 \%( \pm 3.3)$ and $42.4 \%$ ( \pm 3.3$)$ with respect to the untreated control group (see Figure 9A).

Evaluation of cytotoxicity using human mammary carcinoma cells (MCF-7) showed that MSE-NC induced a significant decrease in cell viability, either with or without exposure to AMF, although in a dose-dependent way (see Figure 9B). Under AMF treatment plus incubation with MSE$\mathrm{NC}$ containing $100 \mu \mathrm{g} / \mathrm{mL}$ of selol $+5 \times 10^{9}$ particles $/ \mathrm{mL}$, the MCF-7 cell viability was significantly decreased by $51.8 \%$, whereas with no AMF exposure the cell viability presented with only a $32.2 \%$ reduction.

It is worth mentioning that both neoplastic cell lines used in this study presented a significant decrease in viability when treated with MSE-NC and exposed to the AMF. Incubation of neoplastic cells with MSE-NC only, with no exposure to AMF, promotes much less reduction in cell viability, thus emphasizing the effect of the magnetohyperthermia. As was expected for both cell lines, AMF alone induced no change 

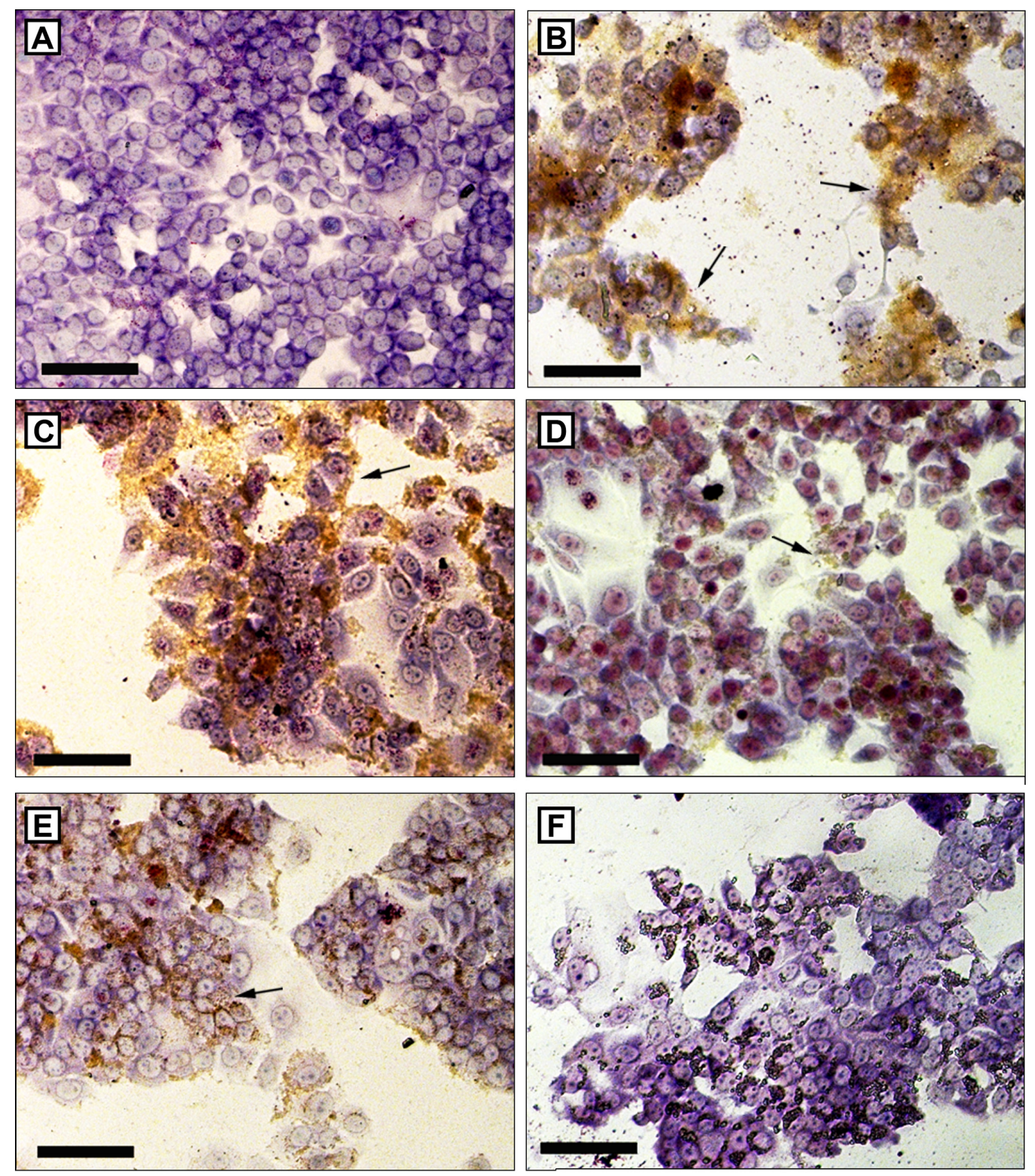

Figure 5 Cell morphology of MCF-7 cells after 48 hours without treatment. Giemsa staining. Arrows indicate clusters of magnetic nanostructures, which can be visualized by brown staining. Figures $\mathbf{A}$ and $\mathbf{B}$ show absence of cluster of magnetic nanostructures. Bars indicate $100 \mu \mathrm{m}$. (A) Treatment with MSE-NC containing $200 \mu \mathrm{g} / \mathrm{mL}$ of selol + I $\times 10^{10}$ particles $/ \mathrm{mL}(8 X) ;\left(\right.$ C) $100 \mu \mathrm{g} / \mathrm{mL}$ of selol + $5 \times 10^{9}$ particles $/ \mathrm{mL}(4 X) ;\left(\right.$ D) $50 \mu \mathrm{g} / \mathrm{mL}$ of selol $+2.5 \times 10^{9}$ particles $/ \mathrm{mL}(2 X) ;\left(\right.$ E) treatment with M-NC (5 $\times 10^{9}$ particles $/ \mathrm{mL}-4 X)$; (F) treatment with SE-NC (I00 $\mu \mathrm{g} / \mathrm{mL}$ of selol $-4 X)$.

Abbreviations: MSE-NC, selol-loaded magnetic nanocapsules; M-NC, unloaded magnetic nanocapsules; SE-NC, nonmagnetic nanocapsules of selol.

in the cell viability as long as no MSE-NC incubation is performed (data not shown).

\section{Discussion}

In this study, MSE-NC presented an antitumor effect in a dose and time dependent way. It is worth mentioning that at low doses, MSE-NC significantly reduced the cell viability of tumor cells (4T1 and MCF-7) with no effects on normal cells (MCF10A). Further, the cytotoxicity to neoplastic cells was even higher when the treatment with MSE-NC was followed by exposure to an AMF. These results illustrate the potential of MSE-NC as an antineoplastic agent either by its action as a selol delivery system, or due to its ability to induce the magnetohyperthermia effect.

It has been shown that the physicochemical characteristics of nanostructures, such as core-shell chemical composition, charge, and size do influence their biological responses. ${ }^{27,28}$ In this context, MNPs with a range of 6 to $10 \mathrm{~nm}$ have been 

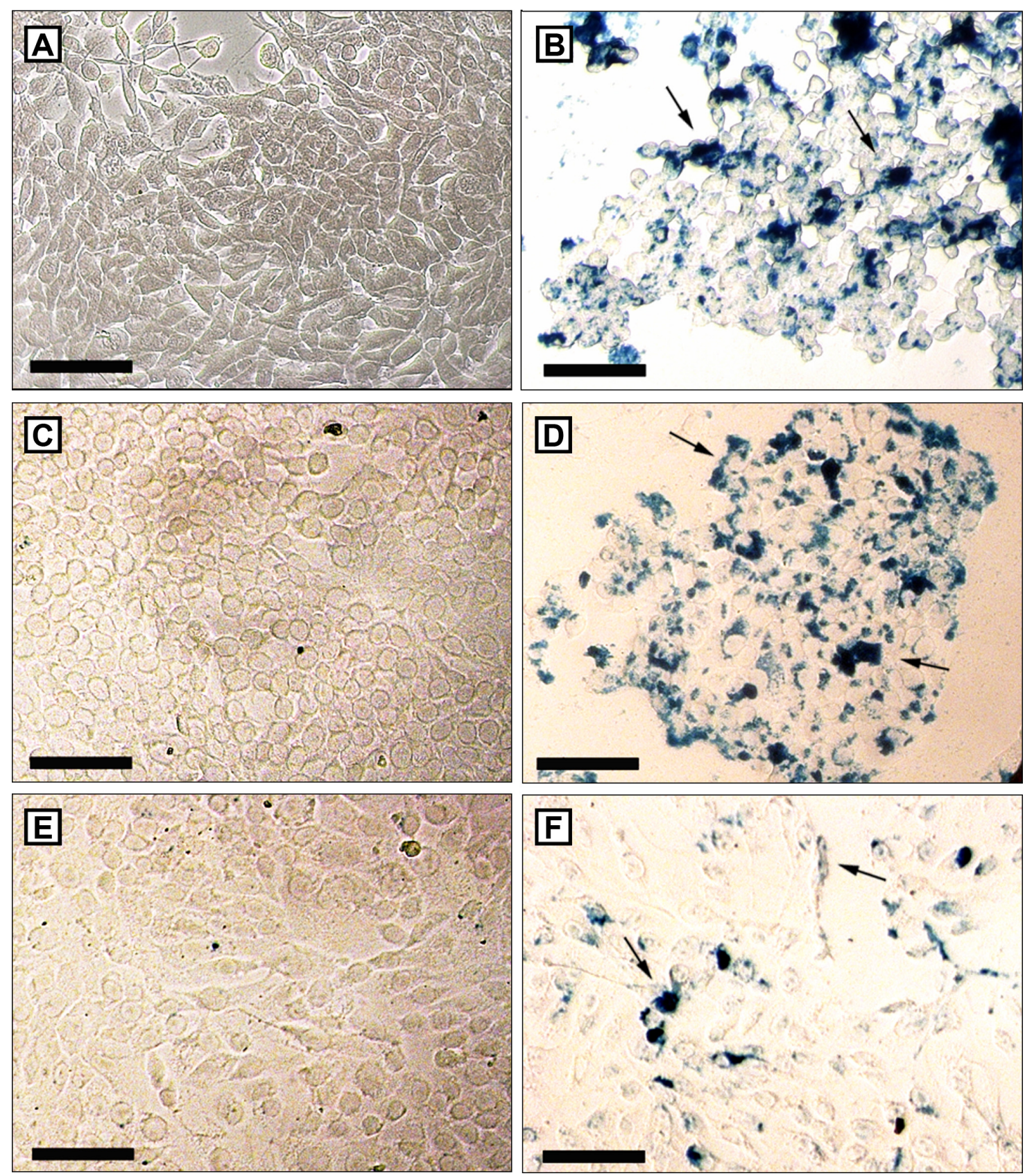

Figure 6 Perls staining of 4TI (A and B), MCF-7 (C and D) and MCF-10A (E and F) after 48 hours without treatment $(\mathbf{A}, \mathbf{C}$ and $\mathbf{E})$ or after the treatment with $100 \mu \mathrm{L} / \mathrm{mL}$ of selol $+5 \times 10^{9}$ particles $/ \mathrm{mL}(4 \mathrm{X})(\mathbf{B}, \mathbf{D}$ and $\mathbf{F})$.

Notes: Clusters of magnetic nanoparticles are stained in blue. Higher amounts of pigment blue are visualized in neoplastic tumor cells. Bars indicate $100 \mu \mathrm{m}$.

appointed as materials with high magnetic applicability. Likewise, 10 to $100 \mathrm{~nm}$ are considered to be the ideal MNP diameters that avoid their recognition by the mononuclear phagocyte system, thus, allowing for a longer stay in the bloodstream, and promoting effective biodistribution. ${ }^{3,29}$ In accordance with this desirable characteristic, maghemite nanoparticles used to prepare the magnetic nanocapsules evaluated in our study presented with a $10.0 \mathrm{~nm}( \pm 2.5 \mathrm{~nm})$ diameter, as observed by TEM micrograph. Further, the possibility of developing highly biocompatible polymericbased magnetic nanostructures using engineered maghemite nanoparticles ${ }^{28}$ that are able to induce magnetohyperthermia was previously demonstrated. ${ }^{14}$ PCS analysis revealed that MSE-NC presents a monodisperse profile (polydispersity index of 0.23), an important feature required to enhance the heating performance. ${ }^{13}$ The high average diameter found in the M-NC sample (949 $\mathrm{nm} \pm 100 \mathrm{~nm}$ ) was mainly a result of nanocapsule aggregation, as evidenced by TEM analysis. 


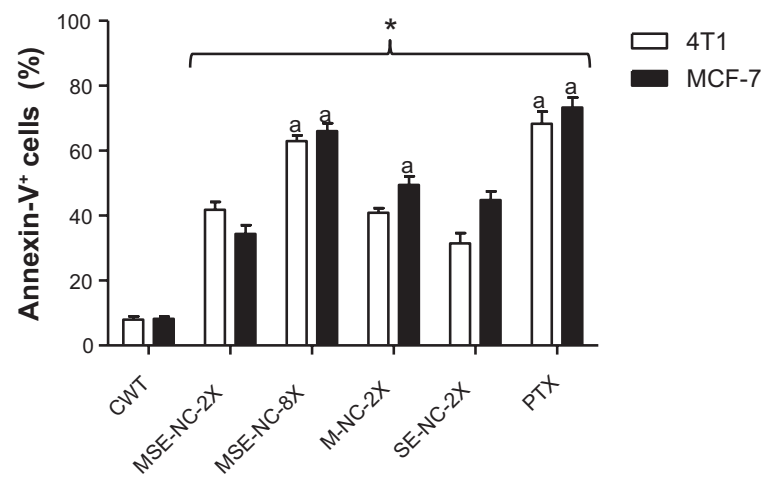

Figure 7 Effects of 48 hours of treatment with nanocapsules MSE-NC, M-NC, and SE-NC on the percentage of cells positively stained for annexin-V.

Notes: Breast carcinoma cells (4TI and MCF-7 lines) were stained with Annexin V-FITC and propidium iodide and analyzed by flow cytometry. Data were normalized with the untreated control and expressed as percentage of the mean \pm SEM of two independent experiments performed in triplicate. *Denotes the statistical difference with respect to the control group without treatment (CWT); ${ }^{\text {denotes the statistical }}$ difference with respect to MSE-NC-2X; $P<0.05$. $2 X=50 \mu \mathrm{g} / \mathrm{mL}$ of selol and/or $2.5 \times 10^{9}$ particles $/ \mathrm{mL} ; 8 X=200 \mu \mathrm{g} / \mathrm{mL}$ of selol $+\mathrm{I} \times 10^{10}$ particles $/ \mathrm{mL}$.

Abbreviations: MSE-NC, PLGA-nanocapsules loaded with magnetic nanoparticles and selol; M-NC, PLGA-nanocapsules loaded with magnetic nanoparticles; SE-NC, PLGA-nanocapsules loaded with selol; CWT, control with no treatment; PTX, Paclitaxel.

The presence of MNPs at the outer surface of nanocapsules plus the absence of selol may be responsible for enhanced MNP aggregation. Also, TEM analyses suggested that the presence of selol increases the entrapment of maghemite nanoparticles, probably due to the chemical bonds between selol, PLGA, and maghemite nanoparticles.

Zeta potential analysis revealed that the MSE-NC sample presented with a positive charge, whereas SE-NC or M-NC

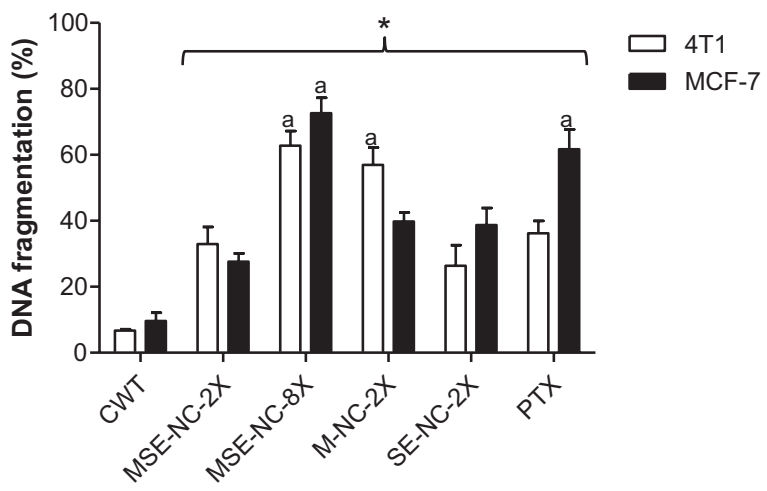

Figure 8 Effects of 48 hours treatment with nanocapsules MSE-NC, M-NC, and SE-NC on the percentage of DNA fragmentation in 4TI and MCF-7 cell lines.

Note: Breast carcinoma cells were stained with propidium iodide and analyzed by flow cytometry. Data were normalized with the untreated control and expressed as percentage of the mean \pm SEM of two independent experiments performed in triplicate. *Denotes the statistical difference with respect to the control group

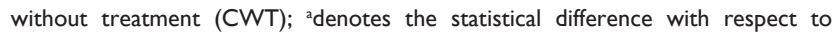
MSE-NC-2X; $P<0.05$. $2 X=50 \mu g / \mathrm{mL}$ of selol and $/$ or $2.5 \times 10^{9}$ particles $/ \mathrm{mL}$; $8 X=200 \mu \mathrm{g} / \mathrm{mL}$ of selol $+1 \times 10^{10}$ particles $/ \mathrm{mL}$.

Abbreviations: MSE-NC, PLGA-nanocapsules loaded with magnetic nanoparticles and selol; M-NC, PLGA-nanocapsules loaded with magnetic nanoparticles; SE-NC, PLGAnanocapsules loaded with selol; CWT, control with no treatment; PTX, Paclitaxel. presented with a negative charge, as usually observed in PLGA formulations. Since selol presented with a positive charge $^{20}$ and ionic magnetic fluids prepared in low $\mathrm{pH}$ also presented with positively-charged nanoparticles, ${ }^{30}$ the coencapsulation of both selol and maghemite nanoparticles overcame the negative charge of PLGA. Moreover, the presence of maghemite nanoparticles at the outer surface of MSE-NC, as observed by TEM, contributed to the net positive charge found in the zeta potential data.

This in vitro study showed that MSE-NC induced dose, time, and cell line-dependent cytotoxicity. Our data are in agreement with previous studies that present selenium-based nanoparticles as a cytotoxic agent to human breast carcinoma cells (MDA-MB-31 ${ }^{19}$ and MCF- $7^{31}$ ), human cervical carcinoma cells (HeLa), ${ }^{19}$ human melanoma cells (A375), ${ }^{31}$ and human hepatic carcinoma cells (Bel7402). ${ }^{32}$ It is worth noting that the two lowest concentrations of MSE-NC used while acting for 48 hours significantly decreased the cell viability of neoplastic cells (4T1 and MCF-7) with no effects on normal cells (MCF10A). The preferential cytotoxicity of MSE-NC to cancer cells was also demonstrated by the $\mathrm{IC}_{50}$ values. This finding is in accordance with previous studies showing that selenium-based nanoparticles presented more cytotoxic effects to tumorigenic cells than to normal cells. ${ }^{31,33}$ Samples of M-NC and SE-NC reduced the cell viability of breast cancer cells in all of the evaluated concentrations, illustrating their cytotoxic effects as well as the intrinsic effect of selol and MNPs as antineoplastic agents. However, in normal breast cells, SE-NC was toxic only at higher concentrations (200 and $400 \mu \mathrm{g} / \mathrm{mL}$ of selol) and after 48 hours of treatment. Furthermore, M-NC was more toxic to normal cells than MSE-NC, suggesting that selol can induce a protective effect for normal cells.

In general, neoplastic cell metabolism is faster than that of normal cells, demanding larger amounts of nutrients, such as iron, which can be evidenced by the presence of more transferrin receptors. ${ }^{34}$ This may explain the evidence obtained from the morphological analysis (Perls' staining) which indicates that MSE-NC is more efficiently taken up by $4 \mathrm{~T} 1$ and MCF-7 tumor cells than MCF-10A normal cells, resulting in higher toxicity to tumor cells than to normal ones. Nevertheless, no change in cell morphology was observed, possibly due to the fact that the analyses were carried out only on cells attached to the plate.

Based on the results of the MTT assay, MSE-NC at a $2 \mathrm{X}$ concentration was used to evaluate the type of cell death and the presence of DNA damage, since this concentration reduced the cell viability of tumorigenic cells with no effect on normal 

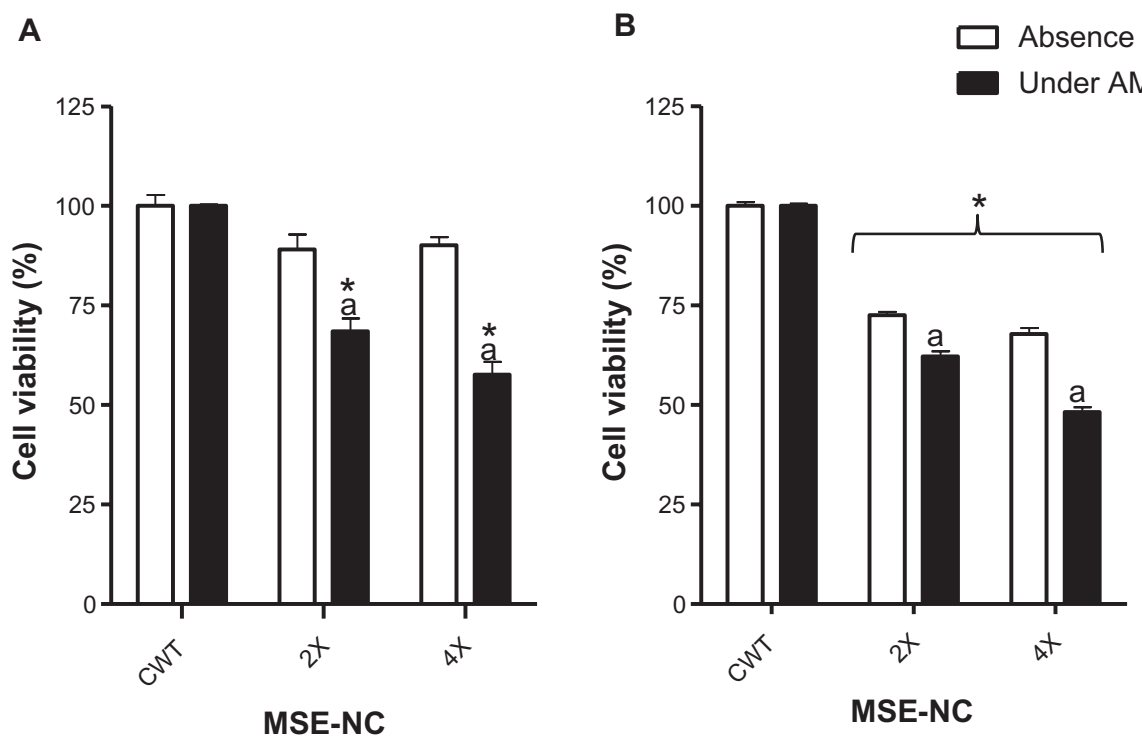

Figure 9 Effects of MSE-NC treatment with or without subsequent exposure to the AMF on the viability of the 4TI (A) and MCF-7 (B) cell lines.

Notes: Data were normalized with the untreated control exposed or not to AMF and expressed as percentage of the mean \pm SEM of three independent experiments performed in triplicate. *Denotes the statistical difference for the CWT; adenotes the statistical difference with respect to the same MSE-NC concentration, but without AMF application; $P<0.05$. The values are as follows: $2 X=50 \mu \mathrm{g} / \mathrm{mL}$ of selol $+2.5 \times 10^{9}$ particles $/ \mathrm{mL} ; 4 X=100 \mu g / \mathrm{mL}$ of selol $+5 \times 10^{9}$ particles $/ \mathrm{mL}$.

Abbreviations: MSE-NC, nanocapsules loaded with magnetic nanoparticles and selol; CWT, control without treatment; AMF, alternating magnetic field.

cells. The $8 \mathrm{X}$ dose was also tested to assess the concentration effects. The induction of apoptosis in neoplastic cells is an important issue of research for new chemotherapy drugs. ${ }^{23}$ The positive staining with annexin- $\mathrm{V}$ in cells is an indication of phosphatidylserine exposure in the plasma membrane, an event closely related to apoptosis. ${ }^{3} \mathrm{~A}$ dose related increase was observed after 48 hours' treatment with MSE-NC ( $50 \mu \mathrm{g} / \mathrm{mL}$ of selol $+2.5 \times 10^{9}$ particles $/ \mathrm{mL}(2 \mathrm{X})$ and $200 \mu \mathrm{g} / \mathrm{mL}$ of selol $+1 \times 10^{10}$ particles $/ \mathrm{mL}(8 \mathrm{X})$ ) while using breast cancer cells positively stained with annexin-V. Our findings are in very good agreement with the findings by Suchocki et al, ${ }^{20}$ which showed that the use of selol induced apoptosis in human leukemia cells. Apoptosis has been described as one of the more important mechanisms for the anticancer action of selenium-based compounds. ${ }^{35-37}$ Although Valdiglesias et $\mathrm{a}^{38}$ reported that the induction of apoptosis by Seleniumbased compounds may be related to changes in the cell cycle, Suchocki et $\mathrm{al}^{20}$ found that free selol did not overset the cell cycle in human leukemia cells.

DNA fragmentation is also an important hallmark of cell apoptosis. An increase in DNA fragmentation was observed after treatment of breast cancer cells with MSE-NC, corroborating the results found in the analysis of phosphatidylserine exposure. Induction of DNA fragmentation was also described by Suchocki et $\mathrm{a}^{20}$ after treating human leukemia cells with selol.

Because magnetic samples can also be used to promote magnetohyperthermia, neoplastic cells treated with MSE-NC were also exposed to the AMF, and the cytotoxic effect of this treatment was evaluated. The methodology was based on previous in vitro experiments performed with the same AMF equipment that was used in this study. ${ }^{24,25}$ Data show that the exposure to an AMF increased the cytotoxic effects on MSE-NC in a dose-dependent way. Further, the AMF was essential to induce significant cytotoxicity on 4T1 cells previously treated with MSE-NC. As expected, AMF alone did not show significant cytotoxic effects on cells (data not shown). In contrast from our findings using mammary carcinoma cells (4T1 and MCF-7), Falqueiro et al ${ }^{24}$ showed that metastatic murine melanoma cells (B16-F10) and oral squamous cell carcinoma treated with MSE-NC $(100 \mu \mathrm{g} / \mathrm{mL}$ of selol $+5 \times 10^{12}$ particles $/ \mathrm{mL}$ ) did not show any significant differences in the viability between the cells that were either exposed or not to the AMF, although the number of maghemite nanoparticles had been higher than that used in our study $\left(5 \times 10^{9}\right.$ particles $\left./ \mathrm{mL}\right)$, evidencing the difference and specificity in the treatment response while using different cell types. In this context, our results show the potential of MSE-NC as an antitumor agent against breast cancer cells, including its efficacy to induce magnetohyperthermia, as already reported in previous in vivo studies. ${ }^{14}$

\section{Conclusion}

This study showed that the as-prepared MSE-NC sample significantly induces cytotoxic effects on breast cancer cell 
lines in a dose and time dependent manner, evidencing its antitumor effect. Further, at low doses, MSE-NC exhibits an antitumor effect while not affecting the viability of normal cells. This may be explained by the enhanced uptake of MSE-NC by neoplastic cells when compared to normal cells. Analysis of phosphatidylserine exposure and DNA fragmentation suggests that apoptosis is the main mechanism of cell death induced by the MSE-NC treatment. Moreover, the antitumor effect of MSE-NC may be increased when exposed to an AMF, showing that this formulation presents adequate magnetic properties for biomedical applications. Therefore, we suggest that MSE-NC should be considered as an effective material system for magnetic drug delivery and as a magnetohyperthermia inductor in antitumor therapy.

\section{Acknowledgments}

The authors acknowledge the financial support of Brazilian agencies Rede CON-NANO/CAPES, INCT-Nanobiotechnologia/MCT/CNPq, FAP-DF, FAPESP (2009/13208-3), DPP/ UnB, CNANO/IB/UnB, and the Polish State Committee for Scientific Research (N N 202 166440, N N 405 360639).

\section{Disclosure}

The authors report no conflicts of interest in this study.

\section{References}

1. Diao YY, Li HY, FuYH, et al. Doxorubicin-loaded PEG-PCL copolymer micelles enhance cytotoxicity and intracellular accumulation of doxorubicin in adriamycin-resistant tumor cells. Int J Nanomedicine. 2011;6: 1955-1962.

2. Kumar CS, Mohammad F. Magnetic nanomaterials for hyperthermiabased therapy and controlled drug delivery. Adv Drug Deliv Rev. 2011;63(9):789-808.

3. Carneiro ML, Nunes ES, Peixoto RC, et al. Free Rhodium (II) citrate and rhodium (II) citrate magnetic carriers as potential strategies for breast cancer therapy. J Nanobiotechnology. 2011;9:11.

4. Lee P, Zhang R, Li V, et al. Enhancement of anticancer efficacy using modified lipophilic nanoparticle drug encapsulation. Int $J$ Nanomedicine. 2012;7:731-737.

5. Wolinsky JB, Colson YL, Grinstaff MW. Local drug delivery strategies for cancer treatment: gels, nanoparticles, polymeric films, rods, and wafers. J Control Release. 2012;159(1):14-26.

6. Haley B, Frenkel E. Nanoparticles for drug delivery in cancer treatment. Urol Oncol. 2008;26(1):57-64.

7. De Jong WH, Borm PJ. Drug delivery and nanoparticles: applications and hazards. Int J Nanomedicine. 2008;3(2):133-149.

8. Danhier F, Ansorena E, Silva JM, Coco R, Le Breton A, Preat V. PLGA-based nanoparticles: an overview of biomedical applications. J Control Release. 2012;161(2):505-522.

9. Danhier F, Lecouturier N, Vroman B, et al. Paclitaxel-loaded PEGylated PLGA-based nanoparticles: in vitro and in vivo evaluation. $J$ Control Release. 2009;133(1):11-17.

10. Fonseca C, Simoes S, Gaspar R. Paclitaxel-loaded PLGA nanoparticles: preparation, physicochemical characterization and in vitro anti-tumoral activity. J Control Release. 2002;83(2):273-286.
11. Davaran S, Rashidi MR, Pourabbas B, Dadashzadeh M, Haghshenas NM. Adriamycin release from poly(lactide-coglycolide)-polyethylene glycol nanoparticles: synthesis, and in vitro characterization. Int $J$ Nanomedicine. 2006;1(4):535-539.

12. Park J, Fong PM, Lu J, et al. PEGylated PLGA nanoparticles for the improved delivery of doxorubicin. Nanomedicine. 2009;5(4): 410-418.

13. Khandhar AP, Ferguson RM, Simon JA, Krishnan KM. Tailored magnetic nanoparticles for optimizing magnetic fluid hyperthermia. J Biomed Mater Res A. 2012;100(3):728-737.

14. Portilho FA, Estevanato LLC, Miranda-Vilela AL, et al. Investigation of a magnetohyperthermia system efficacy. J Appl Phys. 2010;109: $07 \mathrm{~B} 307$.

15. Laurent S, Dutz S, Häfeli UO, Mahmoudi M. Magnetic fluid hyperthermia: focus on superparamagnetic iron oxide nanoparticles. Adv Colloid Interface Sci. 2011;166(1-2):8-23.

16. Falqueiro AM, Primo FL, Morais PC, Mosiniewicz-Szablewska E, Suchocki P, Tedesco AC. Selol-loaded magnetic nanocapsules: a new approach for hyperthermia cancer therapy. J Appl Phys. 2011;109(7):07B306.

17. Fitak B, Grabowski M, Suchocki P, inventors. Poland patent Pol. P1 176530 (Cl. A61K31/095). June 30, 1999.

18. Brozmanova J, Manikova D, Vlckova V, Chovanec M. Selenium: a double-edged sword for defense and offence in cancer. Arch Toxicol. 2010;84(12):919-938.

19. Luo H, Wang F, Bai Y, Chen T, Zheng W. Selenium nanoparticles inhibit the growth of HeLa and MDA-MB-231 cells through induction of S phase arrest. Colloids Surf B Biointerfaces. 2012;94:304-308.

20. Suchocki P, Misiewicz I, Skupinska K, Waclawek K, Fijalek Z, Kasprzycka-Guttman T. The activity of Selol in multidrug-resistant and sensitive human leukemia cells. Oncol Rep. 2007;18(4):893-899.

21. Cao S, Durrani FA, Rustum YM. Selective modulation of the therapeutic efficacy of anticancer drugs by selenium containing compounds against human tumor xenografts. Clin Cancer Res. 2004;10(7):2561-2569.

22. Bee A, Massart R, Neveu S. Synthesis of very fine maghemite particles. J Magn Magn Mater. 1995;149(1-2):6-9.

23. Lu X, Qian J, Zhou H, et al. In vitro cytotoxicity and induction of apoptosis by silica nanoparticles in human HepG2 hepatoma cells. Int J Nanomedicine. 2011;6:1889-1901.

24. Falqueiro AM, Siqueira-Moura MP, Jardim DR, et al. In vitro cytotoxicity of Selol-loaded magnetic nanaocapsules against neoplastic cell lines under AC magnetic field activation. J Appl Phys. 2012;111:07B335.

25. Simioni AR, Primo FL, Rodrigues MMA, Lacava ZGM, Morais PC, Tedesco AC. Preparation, characterization and in vitro toxicity test of magnetic nanoparticle-based drug delivery system to hyperthermia of biological tissues. IEEE Trans Magn. 2007;43(6):2459-2461.

26. Guedes MHA, Guedes MEA, Morais PC, et al. Proposal of a magnetohyperthermia system: preliminary biological tests. J Magn Magn Mater. 2004;272-276:2406-2407.

27. Dobrovolskaia MA, McNeil SE. Immunological properties of engineered nanomaterials. Nat Nanotechnol. 2007;2(8):469-478.

28. Estevanato L, Cintra D, Baldini N, et al. Preliminary biocompatibility investigation of magnetic albumin nanosphere designed as a potential versatile drug delivery system. Int J Nanomedicine. 2011;6:1709-1717.

29. Heath JR, Davis ME. Nanotechnology and cancer. Annu Rev Med. 2008;59:251-265.

30. Morais PC, Garg VK, Oliveira AC, et al. Synthesis and characterization of size-controlled cobalt-ferrite-based ionic ferrofluids. J Magn Magn Mater. 2001;225(1-2):37-40.

31. Yang F, Tang Q, Zhong X, et al. Surface decoration by Spirulina polysaccharide enhances the cellular uptake and anticancer efficacy of selenium nanoparticles. Int J Nanomedicine. 2012;7:835-844.

32. Tan L, Jia X, Jiang X, et al. In vitro study on the individual and synergistic cytotoxicity of adriamycin and selenium nanoparticles against Bel7402 cells with a quartz crystal microbalance. Biosens Bioelectron. 2009;24(7):2268-2272. 
33. Chen T, Wong YS, Zheng W, Bai Y, Huang L. Selenium nanoparticles fabricated in Undaria pinnatifida polysaccharide solutions induce mitochondria-mediated apoptosis in A375 human melanoma cells. Colloids Surf B Biointerfaces. 2008;67(1):26-31.

34. Kwok JC, Richardson DR. The iron metabolism of neoplastic cells: alterations that facilitate proliferation? Crit Rev Oncol Hematol. 2002;42(1):65-78.

35. Lu J, Kaeck M, Jiang C, Wilson AC, Thompson HJ. Selenite induction of DNA strand breaks and apoptosis in mouse leukemic L1210 cells. Biochem Pharmacol. 1994;47(9):1531-1535.
36. Li S, Zhou Y, Wang R, Zhang H, Dong Y, Ip C. Selenium sensitizes MCF-7 breast cancer cells to doxorubicin-induced apoptosis through modulation of phospho-Akt and its downstream substrates. Mol Cancer Ther. 2007;6(3):1031-1038.

37. Shang D, Li Y, Wang C, Wang X, Yu Z, Fu X. A novel polysaccharide from Se-enriched Ganoderma lucidum induces apoptosis of human breast cancer cells. Oncol Rep. 2011;25(1):267-272.

38. Valdiglesias V, Pasaro E, Mendez J, Laffon B. In vitro evaluation of selenium genotoxic, cytotoxic, and protective effects: a review. Arch Toxicol. 2010;84(5):337-351.
International Journal of Nanomedicine

\section{Publish your work in this journal}

The International Journal of Nanomedicine is an international, peerreviewed journal focusing on the application of nanotechnology in diagnostics, therapeutics, and drug delivery systems throughout the biomedical field. This journal is indexed on PubMed Central, MedLine, CAS, SciSearch $®$, Current Contents $® /$ Clinical Medicine,

\section{Dovepress}

Journal Citation Reports/Science Edition, EMBase, Scopus and the Elsevier Bibliographic databases. The manuscript management system is completely online and includes a very quick and fair peer-review system, which is all easy to use. Visit http://www.dovepress.com/ testimonials.php to read real quotes from published authors.

Submit your manuscript here: http://www.dovepress.com/international-journal-of-nanomedicine-journal 